\title{
Synergic and comparative effect of 5-fluorouracil and leucoverin on breast and colon cancer cells through TRPM2 channels
}

\author{
Guler $\mathrm{Y}^{1}$, Ovey $\mathrm{IS}^{2}$ \\ Alanya Alaaddin Keykubat University Medical Faculty, Department of General Surgery, Alanya, Antalya, Turkey. \\ yilmaz.guler@alanya.edu.tr
}

\begin{abstract}
OBJECTIVES: We aimed to reveal the role of 5-fluorouracil (5-FU) and Leucovorin (LV) along with transient receptor potential protein melastatin 2 (TRPM2) channels in breast and colon cancer cells during the treatment process. BACKGROUND: 5-FU and LV are widely used in breast and colon cancers for chemotherapy. It has been reported that the expression of TRPM2 channels increased intensively in cancer cells.

METHODS: Breast (MCF7) and colon (Caco-2) cells were cultured and divided into seven main groups. The cells in the group were incubated with 5-FU and LV for 24 hrs and then incubated with Antranilic acid. The effects of medicines were investigated on all molecular pathways of apoptosis.

RESULTS: It was found that 5FU and LCV, administered separately and together on breast cancer cell culture and colon cancer cell culture increased the intracellular calcium levels by stimulation of TRPM2 channels in both cancer cells.

CONCLUSION: As the result of our study, it has been shown that apoptotic effects of 5FU and LV on both colon and breast cancer cells were directly related to TRPM2 channels and that TRPM2 channels played an important role in the whole molecular pathway of apoptosis leading to increased intracellular $\mathrm{Ca}^{2+}\left(\mathrm{Ca}^{2+}\right)$ levels and increased mitochondrial depolarisation (Fig. 6, Ref. 43). Text in PDF www.elis.sk.

KEY WORDS: breast and colorectal cancers, TRPM2 channel, 5-flourouracil, leucoverin, oxidative stress.
\end{abstract}

\section{Introduction}

Breast and colon cancers are common and are among the major causes of death worldwide. Breast cancer, along with lung cancer, is the one of the leading causes of death among women (1). Colon cancer is the third most common cancer in men after lung and prostate cancers (2). Chemotherapy in breast and colon cancer is widely used during preoperative and postoperative period. As the result of recent studies, significant progress has been made in the treatment with the development of chemotherapy strategies that are applied according to various cancer subtypes and stages, especially in breast cancer (3). 5-fluorouracil (5-FU) is widely used in breast cancers and digestive tract cancers, especially in colon cancers because of its relatively high efficiency and relatively low cost (4). 5-FU is generally used in combination with leucovorin (LV) in clinical chemotherapy applications (5-FU/LV).

Transient receptor potential (TRP) protein was first identified in Drosophila trp genes in 1989 (5). The TRP protein family contains different groups of calcium ion $\left(\mathrm{Ca}^{2+}\right)$ permeable and non-

${ }^{1}$ Alanya Alaaddin Keykubat University Medical Faculty, Department of General Surgery, Alanya, Antalya, Turkey, and ${ }^{2}$ Alanya Alaaddin Keykubat University Medical Faculty, Education and Research Hospital, Department of Physiology, Alanya, Antalya, Turkey

Address for correspondence: Y. Guler, Alanya Alaaddin Keykubat University Medical Faculty Education and Research Hospital, Department of General Surgery Postal Code: 07400 Alanya, Antalya, Turkey.

Phone: +902425134841, Fax: +902425134840 selective cation channels and is found in many living organisms $(6,7,8)$. There are 6 subtypes of TRP channels; TRPC (canonical), TRPV (vanilloid), TRPM (melastatin), TRPP (polycystic kidney disease), TRPML (mucolipin) and TRPA (ankyrin) TRP channels contain tetrameric subunit stoichiometry and each subunit contains cytoplasmic $\mathrm{N}$ and $\mathrm{C}$-terminal regions, 6 transmembrane (TM) domains, and TM5-TM6 interspaces (9). TRP channels are responsive to stimuli such as receptor stimulation, heat, plantderived compounds, environmental irritants, mechanical stress, $\mathrm{pH}$, intra- and extracellular voltage, and respond physiologically and pathologically $(5,6,7-10)$. In addition, TRP channels respond fairly well to oxidative stress mediators such as: reactive oxygen species (ROS), reactive nitrogen species (RNS), and other electrophiles (11-14).

Transient receptor potential melastatin-2 (TRPM2) channels have been reported to have significant effects on migration and cell death in tumour and immune system cells (15). TRPM2 protein has been shown to induce cell death by cytokine and bacterial peptide activation, directly through cell migration and oxidative stress (16). TRPM2 channels have been reported to increase expression intensively in head and neck, bladder, liver, and lung adenocarcinomas, particularly breast cancer (17).

Intracellular $\mathrm{Ca}^{2+}$ is involved in the activation of TRP channels through receptor stimulation and enzymes such as the $\mathrm{Ca}^{2+}$ dependent protein phosphatase, therefore it plays an important role in oxidative stress and apoptosis $(5,18)$. It is known that chemotherapeutic agents increase intracellular $\mathrm{Ca}^{2+}$ levels by free oxygen radi- 
cals in the cell and lead to oxidative stress. It has been reported that 5-FU induces oxidative stress by increasing free oxygen radicals in the cell and causes apoptotic effects in the antioxidant defence system resulting in damage and repression $(19,20)$.

Based on this information, we aimed to investigate the role of TRPM2 channels, which are known to be susceptible to oxidative stress in breast and colon cancer cells, by administering 5-FU and LV on colon and breast cancer cell colonies, both separately and in combination, and to elucidate the effects of these drugs on TRPM2 channels and intracellular $\mathrm{Ca}^{2+}$ levels.

\section{Materials and methods}

\section{Cell culture}

MCF7 and Caco-2 cell line was purchased from Culture Collection of Animal Cells, Foot and Mouth Disease (ŞAP) Institute, Ankara, Turkey. MCF7 cells were cultured in RPMI 1640 medium and Caco-2 cells were cultured in DMEM (Dulbecco's modified Eagle's medium. All mediums containing $10 \%$ foetal bovine serum (FBS) (Fisher Scientific, and $1 \%$ penicillin/streptomycin (Biochrom, Berlin, Germany). The cells were seeded in 8-10 flasks at a density of $1 \times 10^{6}$ cells per flask (filter cap, sterile, $5 \mathrm{ml}, 25 \mathrm{~cm}^{2}$ ). Cells were incubated in T25 flasks at $37^{\circ} \mathrm{C}$ at $5 \%$ $\mathrm{CO}_{2}$ in a humidified incubator. After the cells have reached 75-85 $\%$ confluence, the cells were incubated with the chemical compounds described in the groups section. The cells were examined daily for evidence of contamination. After treatments, the cells were detached with $0.25 \%$ Trypsin-EDTA and split into the sterile falcon tubes for analysis.

\section{Reagents}

Roswell Park Memorial Institute (RPMI) 1640 Medium, Dulbecco's modified Eagle's medium(DMEM), Trypsin-EDTA, Antranilic acid, Fetal Bovine Serum and penicillin-streptomycine, cumenhydroperoxyde and Dimethyl sulfoxide (DMSO) were obtained from Sigma-Aldrich Chemical (St. Louis, MO), Fura-2/AM was obtained from Calbiochem (Darmstadt, Germany). MTT(3-(4,5-Dimethylthiazol-2-yl)-2,5-Diphenyltetrazolium Bromide) was purchased from Thermo Fischer (Waltham, MA USA). Dihydrorhodamine-123 (DHR 123) obtained from Molecular Probes (Eugene, OR, USA). Caspase 3 and Caspase 9 substrates [N-acetyl-Leu-GluHis-Asp-7-amino-4-methylcoumarin (ACLEHD-AMC) and Nacetyl-Leu-Glu-His-Asp-7-amino-4-methylcoumarin(AC-LEHDAMC)] were purchased from Biovision (San Francisco, USA). APOPercentage dye with releasing buffer were purchased from Biocolor (Belfast, Northern Ireland) A mitochondrial stain 5, 5', 6,6'-tetrachloro-1,1',3,3'-tetraethyl benzimidazolyl carbocyanine iodide (JC-1) was purchased from Santa Cruz (Dallas, Texas, USA).

\section{Study groups}

MCF7 and Caco- 2 cells were cultured at $37^{\circ} \mathrm{C}$. The cells were divided into seven main groups.

Group 1 (Control): The cells were not incubated with 5FU, Leucoverin and antranilic acid (ACA), but were kept in a flask containing the same cell culture medium and conditions for $72 \mathrm{~h}$.
Group 2 (5FU): Cells in the group were incubated with $5 \mu \mathrm{M}$ 5-Fluorouracil for $24 \mathrm{hrs} \mathrm{(21).}$

Group 3 (5FU+ACA): Cells in the group were incubated with $5 \mu \mathrm{M} 5$-Fluorouracil for $24 \mathrm{hrs}$ and then incubated with Antranilic acid (ACA, $0.04 \mathrm{mM}, 30 \mathrm{~min}$ ).

Group 4 (5FU+LCV): Cells in the group were incubated with $5 \mu \mathrm{M} 5$-Fluorouracil for $24 \mathrm{hrs}$ and then incubated with $2 \mu \mathrm{M}$ Folinic acid (Leucoverin) for $24 \mathrm{hrs}$.

Group 5 (5FU+LCV+ACA): Cells in the group were incubated with $5 \mu \mathrm{M}$ 5-Fluorouracil for $24 \mathrm{hrs}$ and then incubated with 2 $\mu \mathrm{M}$ Folinic acid (Leucoverin) for $24 \mathrm{hrs}$ and then incubated with Antranilic acid (ACA, $0.04 \mathrm{mM}, 30 \mathrm{~min}$ ).

Group 6 (LCV): Cells in the group were incubated with $2 \mu \mathrm{M}$ Folinic acid (Leucoverin) for $24 \mathrm{hrs} \mathrm{(22).}$

Group 7 (LCV+ACA): Cells in the group were incubated with $2 \mu \mathrm{M}$ Folinic acid (Leucoverin) for $24 \mathrm{hrs}$ and then incubated with Antranilic acid (ACA, $0.04 \mathrm{mM}, 30 \mathrm{~min}$ ).

In related experiments (except for calcium signalling), the cells were further treated with Cumen hydroperoxyde (CMPx) ( $0.1 \mathrm{mM}, 10 \mathrm{~min}$ ) for activation of TRPM2 channel before related analysis and they were also inhibited by the TRPM2 channel blocker ACA (0.04 mM, $30 \mathrm{~min}$ ) before related analysis in the presence of normal extracellular calcium $(1.2 \mathrm{mM})$. During calcium signalling analysis (Fura-2/AM), cells were stimulated on 20th cycles with $0.1 \mathrm{mM} \mathrm{CMPx}$ in the presence of normal extracellular calcium $(1.2 \mathrm{mM})$.

Measurement of intracellular free calcium concentration $\left(\left[\mathrm{Ca}^{2+}\right] \mathrm{i}\right)$

The $\mathrm{Ca}^{2+} \mathrm{i}$ concentration was measured by UV light-excitable Fura-2 acetoxymethyl ester (Fura-2-AM) as an intracellular calcium ion indicator. After cell were incubated with the chemical compounds described in groups section, cells were detached with $0.25 \%$ Trypsin-EDTA from T25 flasks. After centrifuged (100 G, 5 $\mathrm{min}$ ), the medium was removed and replaced with HEPES-buffered saline [HBS; $5 \mathrm{mM} \mathrm{KCl}, 145 \mathrm{mM} \mathrm{NaCl}, 10 \mathrm{mM}$ D-glucose, $1 \mathrm{mM}$ $\mathrm{MgCl}_{2}, 1 \mathrm{mM} \mathrm{CaCl}_{2},(1.2 \mathrm{mM}) .10 \mathrm{mM}$ HEPES and $0.1 \%$ (w/v) bovine serum albumin (BSA); $\mathrm{pH} 7.4$ ] containing $5 \mu \mathrm{M}$ fura-2 AM and $0.05 \%(\mathrm{w} / \mathrm{v})$ Pluronic F-127, and cells were incubated for 1 $\mathrm{h}$ at $37^{\circ} \mathrm{C}$ in the dark. The loaded cells were washed twice with HBS and covered with $1000 \mu \mathrm{L}$ of HBS supplemented with 2.5 $\mathrm{mM}$ probenecid for at least $20 \mathrm{~min}$ at $37{ }^{\circ} \mathrm{C}$ in the dark to allow for Fura-2 AM de-esterification. Cells were seeded in clear flatbottom black 96-well culture trays (Grainer Cell Star, Life Sciences USA) at a density of $3 \times 10^{4}$ cells/per well. Fluorescence emission intensity at $510 \mathrm{~nm}$ was determined in individual wells using a plate reader equipped with an automated injection system (SynergyTM H1, Biotek, USA) at alternating excitation wavelengths of 340 and $380 \mathrm{~nm}$ every $3 \mathrm{~s}$ for 50 acquisition cycles (cycle: $3 \mathrm{~s}$; exposure: 25 flashes; gain: 120) in response to agonists (CMPx, $0.1 \mathrm{mM}$ ) added with the automated injector. $\left[\mathrm{Ca}^{2+}\right] \mathrm{i}$ in cells was expressed as the average emission at $510 \mathrm{~nm}$ in individual wells in response to excitation at $340 / 380 \mathrm{~nm}$ normalized to initial fluorescence emission obtained during the first 10-20 cycles. Measurement of $\left[\mathrm{Ca}^{2+}\right] \mathrm{i}$ was performed as modified by Uguz et al, 2009 and Martinez et al $(23,24)$. 
$692-700$

\section{Intracellular ROS production measurement}

Rhodamine $123(\mathrm{Rh} 123)$ is a non-fluorescent, non-charged dye, which is cell membrane permanent green florescent dye, which can easily pass the cell membranes, where it is oxidized to cationic rhodamine 123, which is localised in the mitochondria and exhibits green fluorescence. It was sequestered by mitochondria. The cells $\left(10^{6}\right.$ cells $/ \mathrm{ml}$ for per group) were incubated with $20 \mu \mathrm{m}$ DHR 123 as florescent oxidant dye at $37^{\circ} \mathrm{C}$ for $25 \mathrm{~min}$ (25). The Rh123 fluorescence intensities were determined by using an automatic microplate reader (Synergy ${ }^{\mathrm{TM}} \mathrm{H1}$, Biotek, USA). Excitation and emission wavelengths of the analyses were $488 \mathrm{~nm}$ and $543 \mathrm{~nm}$, respectively. Data are presented as fold-increase over the pre-treatment level.

\section{Apoptosis assay}

The APOPercentageTM, which is used as an assay for the detection and quantification of apoptosis (Biocolor Ltd., Belfast,
Northern Ireland) was performed according to the manufacturer instructions. The APOPercentageTM assay is a dye-uptake assay, which stains only the apoptotic cells with a red dye. When the membrane of apoptotic cell lost its asymmetry, the APOPercentage dye is bonded with phosphatidyl serine lipids actively and transported into cells, staining apoptotic cells red, thus allowing the detection of apoptosis by a multiplate reader as previously described, elsewhere (26). After the cells were incubated with the chemical compounds described in the groups section, the cells were washed with $1 \mathrm{xPBS}$ and resuspended in $50 \mu \mathrm{l} 1 \mathrm{xPBS}$ for per group. After added $950 \mu 1 \mathrm{1xPBS}$ and $10 \mu \mathrm{l}$ APOPecerntage dye (Biocolor, Belfast, Northern Ireland), than cells were incubated on shaker for $30 \mathrm{~min}$ at $37^{\circ} \mathrm{C}$ in a humidified $\mathrm{CO}_{2}$ incubator in the dark. After the incubation, cells were washed twice by re-suspension in $500 \mu \mathrm{l}$ of $1 \mathrm{xPBS}$ and centrifugation for $5 \mathrm{~min}$ at $1 \mathrm{x} 100$ g. After removing the supernatant, $200 \mu \mathrm{l}$ apopercentage release
(A)

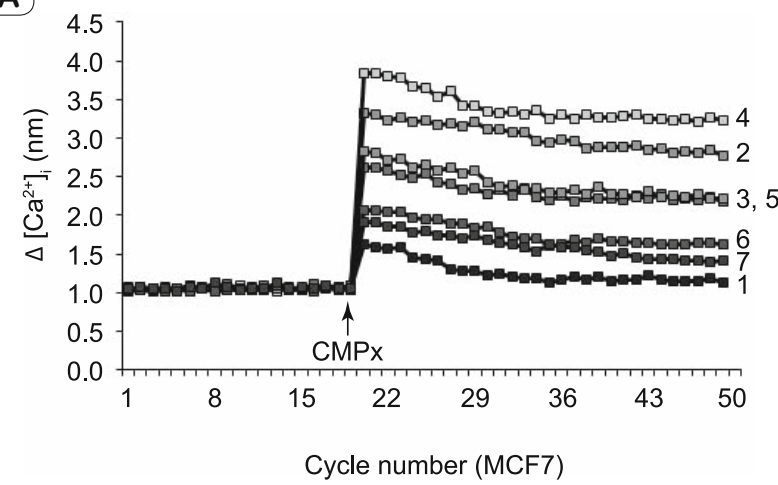

Cycle number (MCF7)
B

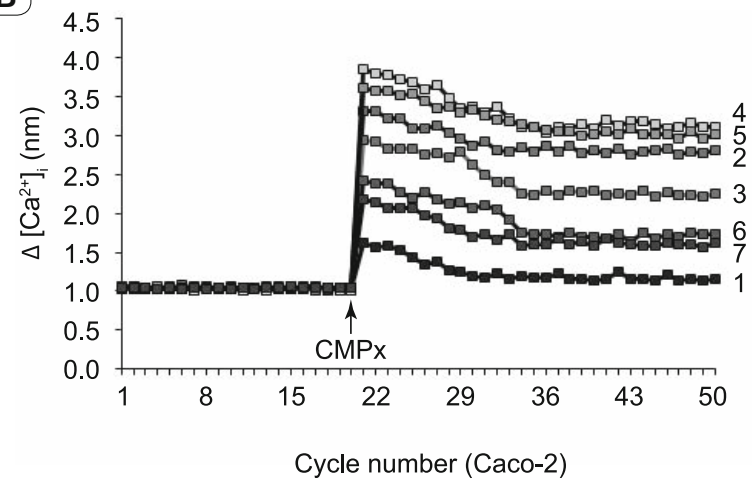

$5-5 \mathrm{FU}+\mathrm{LCV}+\mathrm{ACA}$

6- LCV

$7-\mathrm{LCV}+\mathrm{ACA}$
$6-\mathrm{LCV}$

$7-\mathrm{LCV}+\mathrm{ACA}$

$$
\begin{aligned}
& 1-\text { Control } \\
& 2-5 F U \\
& 3-5 F U+A C A \\
& 4-5 F U+L C V
\end{aligned}
$$

C

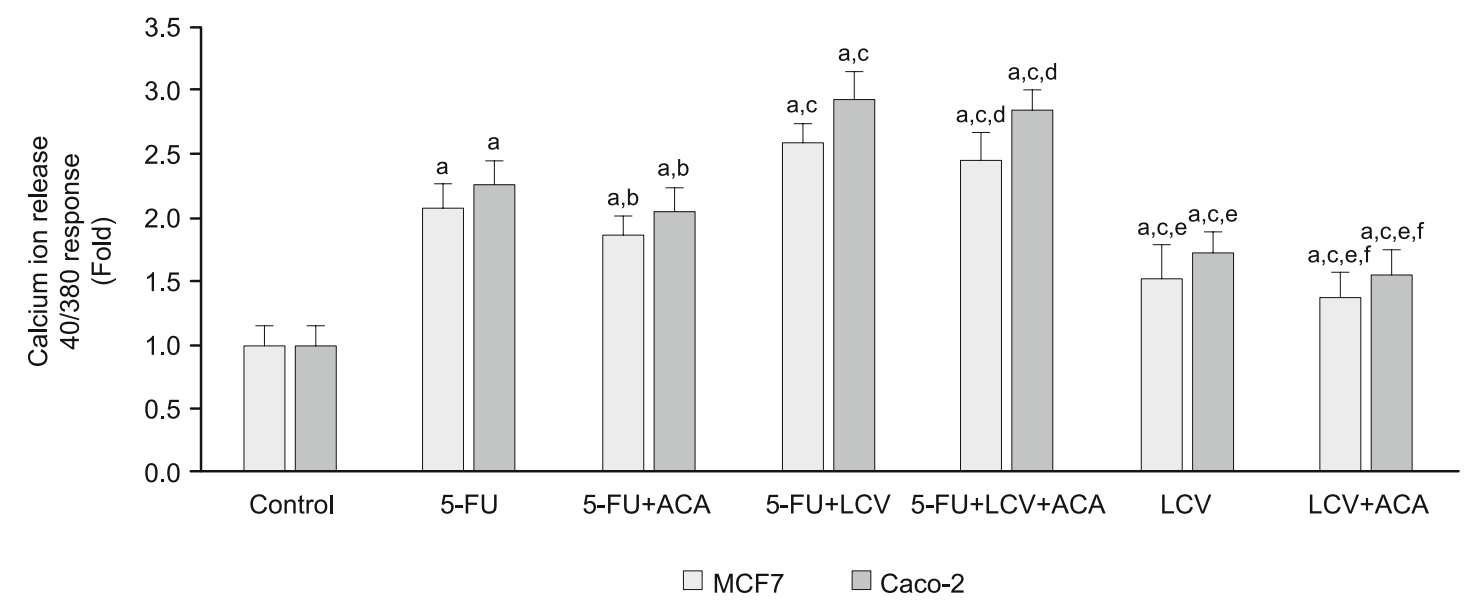

Fig. 1. The effect of 5-FU ( $5 \mu \mathrm{M}, 24 \mathrm{hrs})$ and Leucoverin $(2 \mu \mathrm{M}, 24 \mathrm{hrs})$ on $\left[\mathrm{Ca}^{2+}\right]$ through TRPM2 channels in MCF7 (A) and Caco-2 (B) cells and cellular calcium ion release (fold) (C). Cells are stimulated by Cumene hydroperoxide (CMPX $0.1 \mathrm{mM}$ for 10 min) but they were inhibited by Antranilic Acid (ACA $0.04 \mathrm{mM}$ for $30 \mathrm{~min}$ ) (mean \pm SD and $\mathbf{n}=10$ ). ${ }^{\text {ap }}<0.001$ versus control group, ${ }^{\mathrm{b}} \mathrm{p}<0.05$ and ${ }^{\mathrm{c}} \mathbf{p}<\mathbf{0 . 0 0 1}$ versus $5 \mathrm{FU}$ group, ${ }^{\mathrm{d}} \mathrm{p}<0.05$ and ${ }^{\mathrm{e}} \mathrm{p}<0.001$ versus $5-\mathrm{FU}+\mathrm{LCV}$ group, ${ }^{\mathrm{f}} \mathrm{p}<0.05$ versus $\mathrm{LCV}$ group. 
solution was added. The cells were transferred to transparent plate as $50 \mu \mathrm{l}$ volume for per well and allowing detection of apoptosis by spectrophotometry at $550 \mathrm{~nm}$ (Synergy ${ }^{\mathrm{TM}} \mathrm{H1}$, Biotek, USA).

\section{Assay for caspase-3 and caspase-9 activities}

The determinations of caspase 3 and caspase 9 activities were based on methods previously reported $(27,28)$. MCF7 and Caco-2 cells were sonicated, and cell lysates were incubated with $2 \mathrm{ml}$ of substrate solution (20 mM HEPES [pH 7.4], 2 mM EDTA, $0.1 \%$ CHAPS, $5 \mathrm{mM}$ DTT and $8.25 \mathrm{lM}$ of caspase substrate) for $1 \mathrm{~h}$ at $37^{\circ} \mathrm{C}$. Caspase 3 substrate (NAcetyl-Asp-Glu-Val-Asp-7-amido4-Methylcoumarin) (ACDEVD-AMC) and caspase 9 substrate (Ac-Leu-Glu-His-Asp-7-Amino-4-methylcoumarin) (AC-LEHDAMC) cleavages were measured with the microplate reader (Synergy $^{\mathrm{TM}} \mathrm{H} 1$, Biotek, USA) with excitation wavelength of $360 \mathrm{~nm}$ and emission at $460 \mathrm{~nm}$. The data were calculated as fluorescence units/mg protein and presented as fold-increase over the pre-treatment level (experimental/control).

\section{Mitochondrial membrane potential (JC-1) analyses}

The cells were incubated with JC-1 $(1 \mu \mathrm{M}$ concentration of 5,50,6,60-tetrachloro-1,10,3,30-tetraethylbenzimi-dazolylcarbocyanine iodide) at $37^{\circ} \mathrm{C}$ for $45 \mathrm{~min}$. JC-1 fluorescence was measured by a single excitation wavelength $(488 \mathrm{~nm})$ with dual emission, green $(520 \mathrm{~nm})$ and red $(596 \mathrm{~nm})$ using the microplate reader (Synergy $^{\mathrm{TM}}$ H1, Biotek, USA). (29,30). The lipophilic cationic dye, JC-1, exhibits potential-dependent accumulation in mitochondria. It indicates mitochondrial depolarization by a decrease in the red-to-green fluorescence intensity ratio. After incubation with JC-1, the dye was removed, and the cells were washed in PBS. The green JC-1 signal was measured at the excitation wavelength of $485 \mathrm{~nm}$ and the emission wavelength of $535 \mathrm{~nm}$, and the red signal, at the excitation wavelength of $540 \mathrm{~nm}$ and the emission wavelength of $590 \mathrm{~nm}$. Fluorescence changes were analysed using a fluorescence spectrophotometer (Synergy ${ }^{\mathrm{TM}} \mathrm{H} 1$, Biotek, USA).
Treatments were carried out in triplicate. Data are presented as emission ratios (590/535). Changes in mitochondrial membrane potential were quantified as the integral of the decrease in JC-1 fluorescence ratio of experimental/control.

\section{Cell viability (MTT) assay}

MTT Cell viability analysis was evaluated by the MTT assay based on the ability of viable cells to convert a water-soluble, yellow tetrazolium salt into a water-insoluble, purple formazan product. Cells were incubated with the chemical compounds described in the groups section. After treatments, the cells were washed and incubated with fresh Dulbecco's modified Eagle's medium (DMEM) containing MTT $(0.5 \mathrm{mg} / \mathrm{ml})$ at $37{ }^{\circ} \mathrm{C}$ for $90 \mathrm{~min}(31)$. Then, the supernatant was discarded and dimethyl sulfoxide was added to dissolve the formazan crystals. Optical density was measured in an automatic microplate reader (Synergy ${ }^{\mathrm{TM}} \mathrm{H} 1$, Biotek, USA) at a test wavelength of $490 \mathrm{~nm}$ and a reference wavelength of $650 \mathrm{~nm}$ to nullify the effect of cell debris. The data are presented as fold-increase over the pre-treatment level (experimental/control).

\section{Statistical analyses}

All results were expressed as the means \pm standard deviation (SD). Significant values in the groups were assessed with ANOVA and Mann-Whitney U test. Data were analysed using the SPSS statistical program (version 9.05 software, SPSS Inc. Chicago, Illinois, USA) $\mathrm{p}<0.05$ was considered significant.

\section{Results}

Effects of extracellular 5FU and LCV treatments on CMPX-induced $\left(\mathrm{Ca}^{2+}\right)$ i concentration through TRPM2 channels activation in the MCF7 and Caco-2 cells

As the result of administration of 5-FU and LCV separately and together on breast cancer cell culture (MCF7) and colon cancer cell culture (Caco2), these agents increased the intracellular

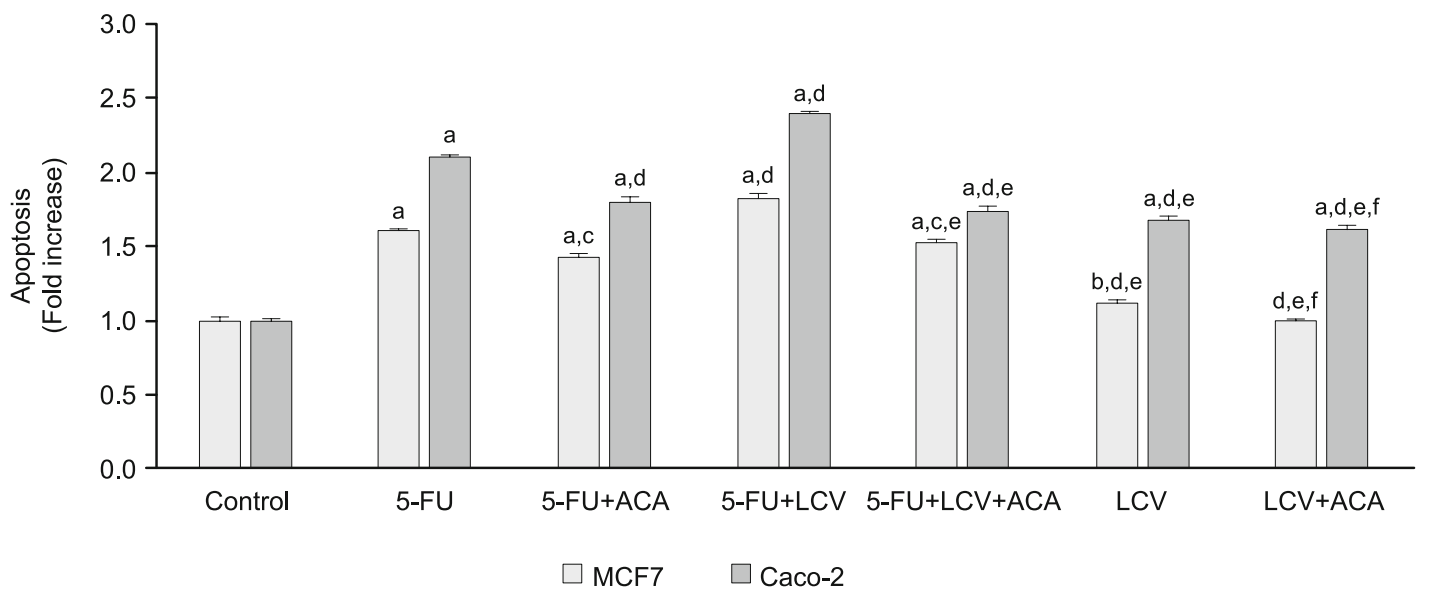

Fig. 2. The effect of 5-FU (5 $\mu \mathrm{M}, 24 \mathrm{hrs})$ and Leucoverin $(2 \mu \mathrm{M}, 24 \mathrm{hrs})$ on apoptosis levels in the MCF7 and Caco2 cells. Cells are stimulated by Cumene hydroperoxide (CMPx $0.1 \mathrm{mM}$ for $10 \mathrm{~min}$ ) but they were inhibited by Antranilic Acid (ACA $0.04 \mathrm{mM}$ for $30 \mathrm{~min}$ ) (mean \pm SD and $\mathbf{n}=10)$. ${ }^{\mathrm{a}} \mathbf{p}<\mathbf{0 . 0 0 1}$ and ${ }^{\mathrm{b}} \mathbf{p}<\mathbf{0 . 0 5}$ versus control group, ${ }^{\mathrm{c}} \mathbf{p}<\mathbf{0 . 0 5}$ and ${ }^{\mathrm{d}} \mathbf{p}<\mathbf{0 . 0 0 1}$ versus 5 -FU group, ${ }^{\mathrm{e}} \mathbf{p}<\mathbf{0 . 0 0 1}$ versus 5 -FU+LCV group and ${ }^{\mathrm{f} p}$ $<0.05$ versus $\mathrm{LCV}$ group. 
$692-700$

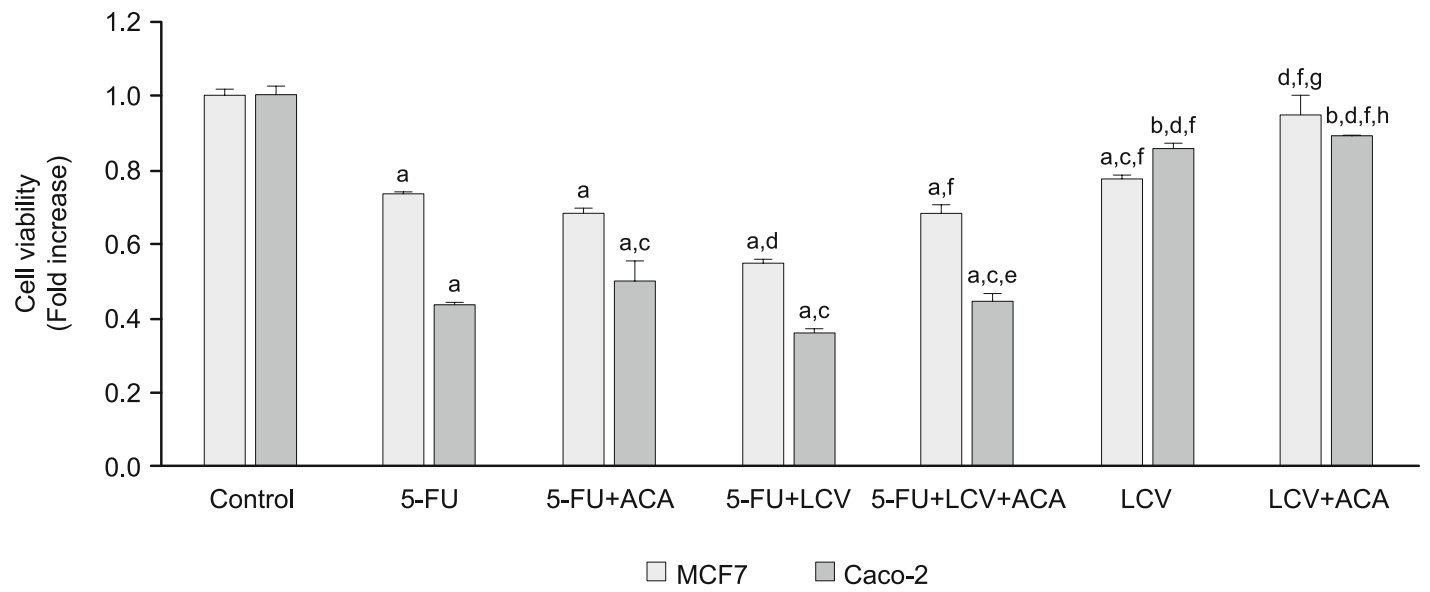

Fig. 3. The effect of 5-FU (5 $\mu \mathrm{M}, 24 \mathrm{hrs})$ and Leucoverin $(2 \mu \mathrm{M}, 24 \mathrm{hrs})$ on Cell Viability levels in the MCF7 and Caco2 cells. Cells are stimulated by Cumene hydroperoxide (CMPx $0.1 \mathrm{mM}$ for $10 \mathrm{~min}$ ) but they were inhibited by Antranilic Acid (ACA $0.04 \mathrm{mM}$ for $30 \mathrm{~min}$ ) (mean \pm SD and $\mathrm{n}=10$ ). ${ }^{\mathrm{a}} \mathrm{p}<\mathbf{0 . 0 0 1}$ and ${ }^{\mathrm{b}} \mathrm{p}<0.05$ versus control group, ${ }^{\mathrm{c}} \mathrm{p}<0.05$ and ${ }^{\mathrm{d}} \mathrm{p}<0.001$ versus 5 -FU group, ${ }^{\mathrm{e}} \mathrm{p}<0.05$ and ${ }^{\mathrm{f}} \mathrm{p}<0.001$ versus 5 -FU $+\mathrm{LCV}$ group, ${ }^{\mathrm{g} p}<0.001$ and ${ }^{\mathrm{h}} \mathrm{p}<0.05$ versus LCV group.

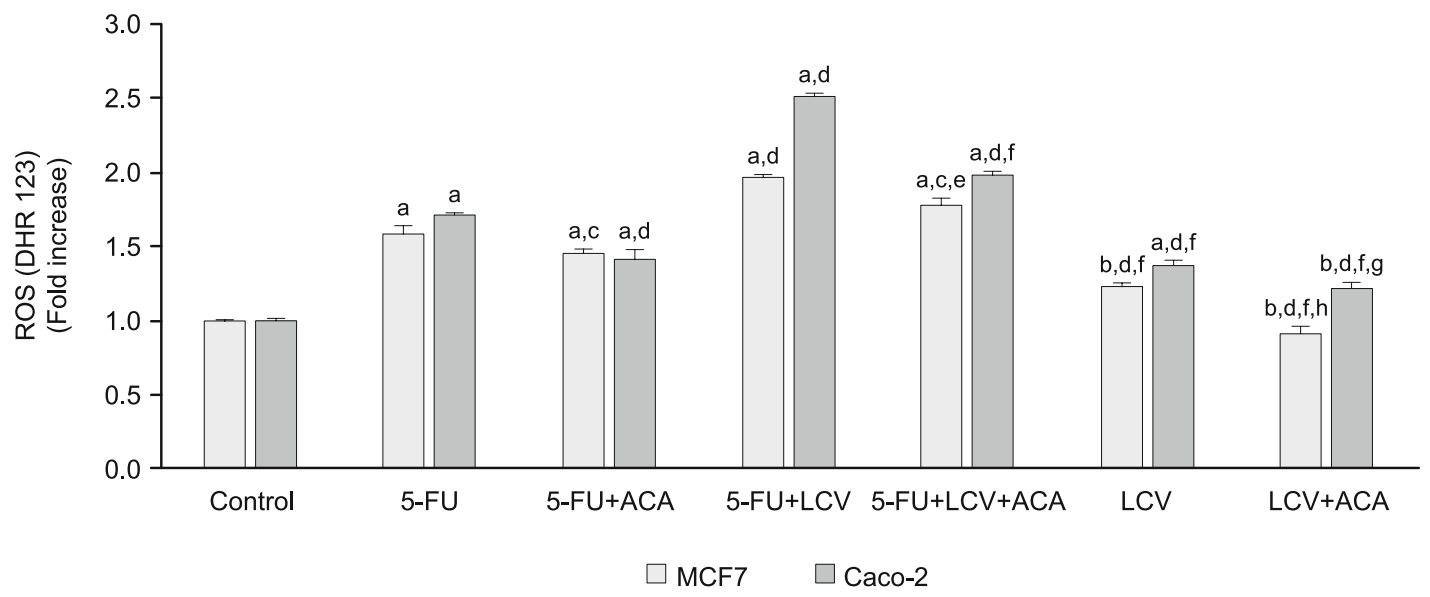

Fig. 4. The effect of 5-FU ( $5 \mu \mathrm{M}, 24 \mathrm{hrs})$ and Leucoverin $(2 \mu \mathrm{M}, 24 \mathrm{hrs})$ on Reactive Oxygene Species levels in the MCF7 and Caco2 cells. Cells are stimulated by Cumene hydroperoxide (CMPx $0.1 \mathrm{mM}$ for $10 \mathrm{~min}$ ) but they were inhibited by Antranilic Acid (ACA $0.04 \mathrm{mM}$ for $30 \mathrm{~min}$ ) (mean \pm SD and $n=10$ ). ${ }^{\text {a }}$ < $<0.001$ and ${ }^{b} p<0.05$ versus control group, ${ }^{\mathrm{c}} \mathrm{p}<0.05$ and ${ }^{\mathrm{d}} \mathrm{p}<0.001$ versus 5 -FU group, ${ }^{\mathrm{e}} \mathrm{p}<0.05$ and ${ }^{\mathrm{f}} \mathrm{p}<0.001$ versus 5-FU+LCV group, ${ }^{\mathrm{g}} \mathrm{p}<0.05$ and ${ }^{\mathrm{h}} \mathrm{p}<0.001$ versus $\mathrm{LCV}$ group.

calcium $\left(\mathrm{Ca}^{2+}\right)$ levels by stimulation of TRPM2 channels in both cancer cells statistically significantly compared to the control group. Intracellular $\left(\mathrm{Ca}^{2+}\right)$ levels were significantly increased $(\mathrm{p}$ $<0.05)$ by the use of TRPM2 channel stimulator (CMPx) in both cancer cells, especially in colon cancer, while using the TRPM2 channel inhibitor (ACA) reduced intracellular $\left(\mathrm{Ca}^{2+}\right)$ levels at a significant level $(\mathrm{p}<0.001)$. Use of 5-FU and LV separately also showed these effects at a statistically significant level (stimulation: $\mathrm{p}<0.05$, inhibition: $\mathrm{p}<0.001$ ) (Fig. 1).

Results of Apoptosis, MTT, ROS, Mitochondrial Depolarisation and Caspase 3 - Caspase 9 Values in MCF7 and Caco-2 Cells

5-FU and LCV were administered separately and together to investigate the degree of apoptosis and cell viability. It was concluded that administration of TRPM2 channel stimulator (CMPx) in both cancer cells significantly increased a degree of apoptosis and decreased cell viability levels compared to the control group $(p<0.001)$, whereas the use of TRPM2 channel inhibitor (ACA), significantly decreased degree of apoptosis and increased cell viability levels $(p<0.05)$. It was found that this effect was statistically more significant in the 5-FU/LV combination group compared to the LV- only group ( $<<0.05)$ (Figs 2 and 3 ).

As the result of investigation of mitochondrial depolarization levels and caspase 3 and caspase 9 levels after administration of 5-FU and LCV separately and in combination, it was found that Reactive Oxygen Species (ROS), mitochondrial depolarization and caspase 3 and caspase 9 levels in both cancer cells were statistically higher with the use of the TRPM2 channel stimulator (CMPx) compared to the control group $(\mathrm{p}<0.001)$, whereas with use of the TRPM2 channel inhibitor (ACA), ROS and mitochon- 


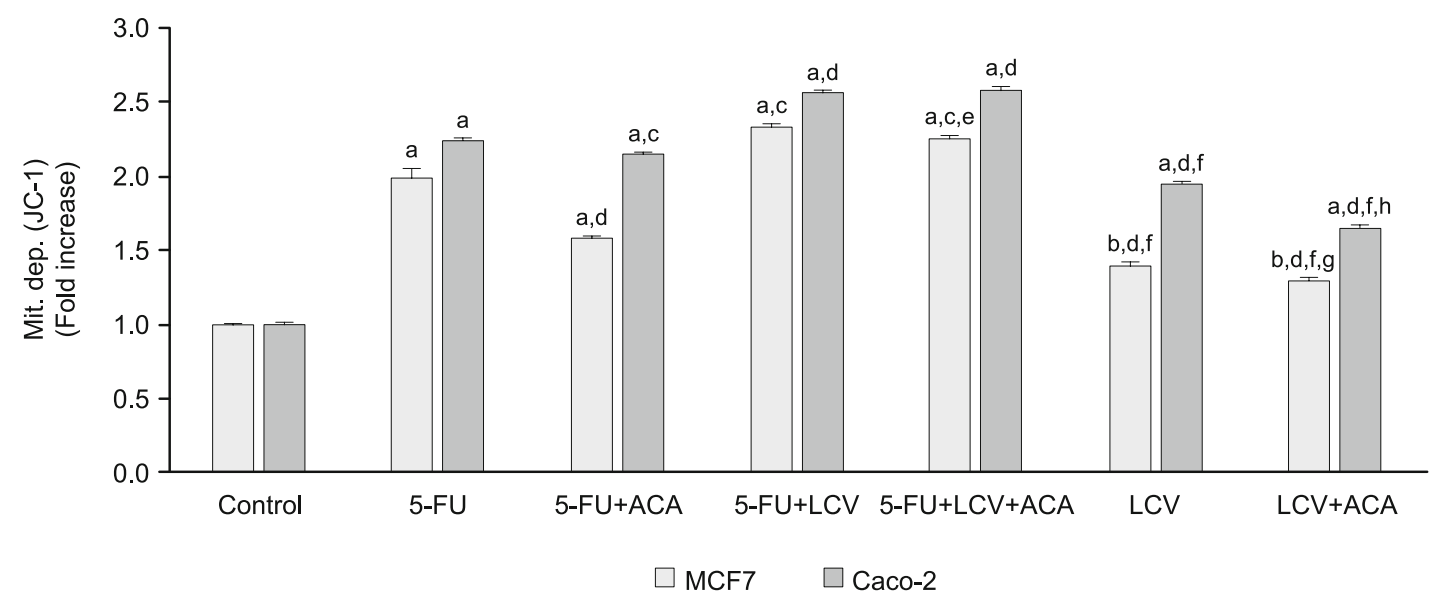

Fig. 5. The effect of 5-FU (5 $\mu \mathrm{M}, 24 \mathrm{hrs})$ and Leucoverin $(2 \mu \mathrm{M}, 24 \mathrm{hrs})$ on Mitochondrial Depolarization levels in the MCF7 and Caco2 cells. Cells are stimulated by Cumene hydroperoxide (CMPx $0.1 \mathrm{mM}$ for $10 \mathrm{~min}$ ) but they were inhibited by Antranilic Acid (ACA $0.04 \mathrm{mM}$ for 30 min) $($ mean \pm SD and $n=10)$. ${ }^{\mathrm{a}} \mathrm{p}<0.001$ and ${ }^{\mathrm{b}} \mathrm{p}<0.05$ versus control group, ${ }^{\mathrm{c}} \mathrm{p}<0.05$ and ${ }^{\mathrm{d}} \mathrm{p}<0.001$ versus 5 -FU group, ${ }^{\mathrm{e}} \mathrm{p}<0.05$ and ${ }^{\mathrm{f}} \mathrm{p}<0.001$ versus 5-FU+LCV group, ${ }^{\mathrm{g}} \mathrm{p}<0.05$ and ${ }^{\mathrm{h} p}<0.001$ versus $\mathrm{LCV}$ group.

drial depolarization along with caspase 3 and caspase 9 levels were reduced significantly $(\mathrm{p}<0.05)$. It was found that these effects were statistically more significant in the 5 -FU/LV combination group compared to the LV-alone group ( $\mathrm{p}<0.001$ ) (Figs 4, 5 and 6).

\section{Discussion}

Breast and colon cancers are the most common cancers in the world and are among the leading causes of mortality. In the treatment of both cancers, various chemotherapy protocols are widely used in preoperative and postoperative periods. 5-FU chemotrapide, is widely used mainly in colon cancers, and is generally used in combination with 5-FU and LV (4).

TRP channels have 6 different subtypes in mammals; TRPA, TRPC, TRPM, TRPML, TRPP and TRPV. The selectivity of TRP channels has a wide spectrum, ranging from nonselective cation channels to highly selective $\left(\mathrm{Ca}^{2+}\right)$ channels. TRP channels respond to a variety of stimuli such as: ligands, heat, mechanical stimulation, and play a role in different processes such as intracellular $\left(\mathrm{Ca}^{2+}\right)$ metabolism, phagocytosis, cell motility, haemostasis, and inflammation (32-34). A number of studies revealed the effects of subpopulations of TRP channels on many different cancer cells and the relationship between the survival and the expression of TRP channels in these cancers have been clearly demonstrated (35).

Many recent studies showed an abnormal TRP channel expression in different types of cancer, and TRP channels have been reported to have effects on invasion, proliferation, differentiation, and tumour vascularization in cancer cells (36). TRPM2 channels have been reported to have abnormal expression and roles in many types of cancer, including adenocarcinoma, among which breast cancer is one of the most important malignancies. In one study, TRPM2 expression was significantly higher in in-situ breast cancer compared to the normal breast tissue, and TRPM2 expression in invasive breast cancer was reported to be 6 -fold higher than in-situ cancer (15). The same study reported that TRPM2 could be used as a molecular biomarker for breast cancer invasion.

It is well known that intracellular $\left(\mathrm{Ca}^{2+}\right)$ levels have significant impact on cancer cells and TRP channels, and they have important roles in intracellular oxidative stress and apoptosis. It has been shown that TRP channels altered intracellular calcium concentrations and they had influence on regulation of $\left(\mathrm{Ca}^{2+}\right)$ release in numerous cell organelles (37). Intracellular $\left(\mathrm{Ca}^{2+}\right.$ concentration is variable and has been reported to increase in cases such as: increased proliferation, apoptosis and abnormal differentiation, which are indicative of cancer invasion $(18,38)$. 5-FU, used therapeutically in many types of cancer, including breast and colon cancer, kills cancer cells by extremely increasing the amount of intracellular ROS (39). Increased intracellular ROS levels trigger oxidative stress, resulting in irreversible changes in components such as: intracellular lipids, proteins, and nucleic acids (40). The increase in intracellular $\left(\mathrm{Ca}^{2+}\right)$ levels leads to an increase in the amount of ROS, mitochondrial membrane depolarization and an increase in activation of caspase 3 and caspase $9(23,30,41)$.

In our study, 5-FU and LV were administered separately and in combination on breast cancer cell culture (MCF7) and colon cancer cell culture (Caco2). Then the effects of these chemotherapeutic agents on TRPM 2 channels and the effects of these channels on cell death were investigated. A specific stimulator (CMPx) and inhibitor (ACA) for TRPM2 channels were administered and the intracellular $\left(\mathrm{Ca}^{2+}\right)$ level, mitochondrial depolarization, caspase 3 and 9 values and intracellular ROS levels as well as degree of apoptosis were investigated by examining the intermediate stages of apoptosis of cancer cells and the results were compared to the control group. As the result of the analysis, it was found that the use of both drugs resulted in TRPM2 channel activation and that there was a significant increase in intracellular $\left(\mathrm{Ca}^{2+}\right)$ levels, mitochondrial depolarization levels and intracellular ROS levels mediated by TRPM2 channels in the 5-FU, 5-FU+LCV groups 
$692-700$

A

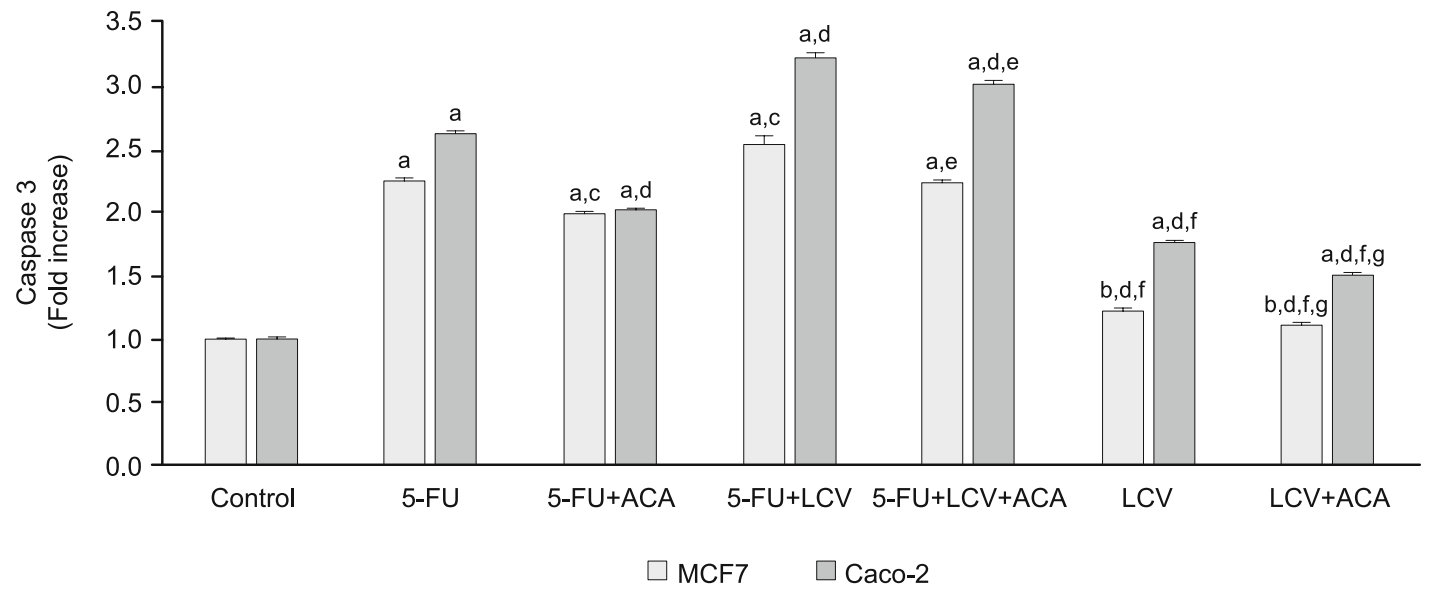

(B)

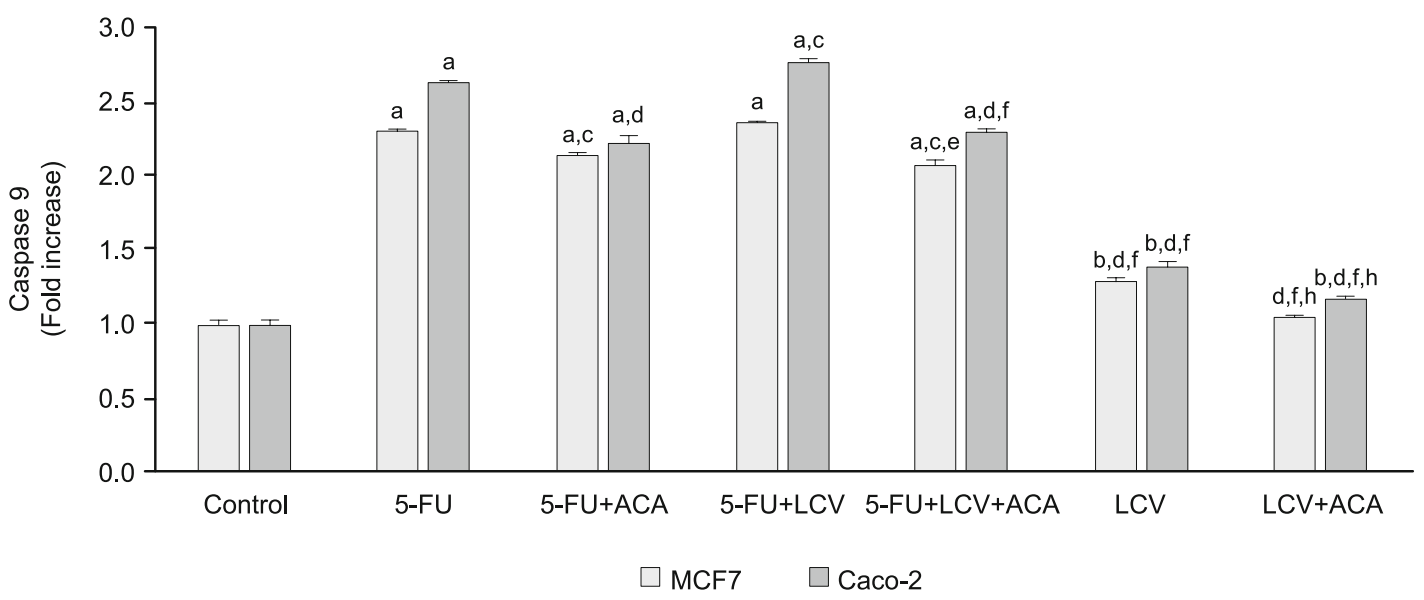

Fig. 6. The effect of 5-FU (5 $\mu \mathrm{M}, 24 \mathrm{hrs})$ and Leucoverin $(2 \mu \mathrm{M}, 24 \mathrm{hrs})$ on Caspase 3 (A) and Caspase 9 (B) levels in the MCF7 and Caco2 cells. Cells are stimulated by Cumene hydroperoxide (CMPx $0.1 \mathrm{mM}$ for $10 \mathrm{~min}$ ) but they were inhibited by Antranilic Acid (ACA $0.04 \mathrm{mM}$ for 30 min) (mean \pm SD and $n=10$ ). ${ }^{\text {a }} p<0.001$ and ${ }^{\mathrm{b}} \mathbf{p}<0.05$ versus control group, ${ }^{\mathrm{c}} \mathrm{p}<\mathbf{0 . 0 5}$ and ${ }^{\mathrm{d}} \mathrm{p}<0.001$ versus 5 -FU group, ${ }^{\mathrm{e}} \mathrm{p}<0.05$ and ${ }^{\mathrm{f}} \mathrm{p}$ $<0.001$ versus $5-\mathrm{FU}+\mathrm{LCV}$ group, ${ }^{\mathrm{g}} \mathrm{p}<0.05$ versus $\mathrm{LCV}$ group.

and the oxidative stress-induced apoptosis levels were significantly increased compared to the control group. TRPM2 channel inhibition resulted in a statistically significant decrease in intracellular $\left(\mathrm{Ca}^{2+}\right)$ levels, mitochondrial depolarization levels and intracellular ROS levels and degree of apoptosis in the 5-FU+ACA, 5-FU+LCV+ACA groups compared to the groups without channel inhibition $(\mathrm{p}<0.05)$. MCF7 and Caco 2 cells showed a statistically significant increase in apoptosis levels $(\mathrm{p}<0.001)$ in the 5 -FU and $5-\mathrm{FU}+\mathrm{LCV}$ groups compared to the control group. Furthermore, the comparison of these effects of 5-FU and LV on both cancer types revealed that TRPM2 and all stages of cell death process were higher in colon cancer, being more pronounced in the 5-FU/ LV combination. It was seen that 5-FU application alone had higher effects than LV alone $(\mathrm{p}<0.001)$.

According to our literature review, there are very limited studies in literature on the effects of chemotherapeutic agents on TRP channels in colon and breast cancer, but no study has examined the effects of chemotherapeutic agents on TRPM2 channels in these cancers. In one study, TRPC5, another channel type that is active in oxidative stress in 5-FU chemoresistant colon cells, has been shown to play an important role (36). In another study regarding the effects of 5-FU on breast cancer cell culture on TRP channels and cell death, 5-FU was administered at a higher dose than our study ( $25 \mu \mathrm{M}, 24 \mathrm{hrs})$. Similar to our study, where 5-FU was administered at a dose of $5 \mu \mathrm{M}$ for 24 hours, they reported that 5-FU showed similar effect at all stages of the molecular pathway of apoptosis by increasing intracellular $\left(\mathrm{Ca}^{2+}\right)$ levels through TRPV1 channel activation (42). Increased TRPC5 expression in colon cancers was reported in literature (43), although TRPM2 channels were reported to play a role in tumour proliferation in breast cancer and may be used as invasion markers and play a role as prognostic factors (15). However, our study has established for the first time that TRPM2 channels had similar effects on colon cancer cells. 
As the result of this study, we conclude that the apoptotic effects of 5-FU and LV, agents frequently used together for colon and breast cancer, were directly related to the TRPM2 channels and that these channels play an important role in all molecular pathways of apoptosis by elevating intracellular levels of $\left(\mathrm{Ca}^{2+}\right)$ and increasing mitochondrial depolarization. In addition, the results of our analyses showed that apoptotic activity of 5-FU+LCV combination in MCF7 and Caco2 cells involved TRPM2 channels and effect of 5-FU/LV on cell death through TRPM2 channels in colon cancer cells (Caco2) was higher than that of the breast cancer.

\section{References}

1. Benson JR, Jatoi I. The global breast cancer burden. Future Oncol 2012; 8: 697-702.

2. Ferlay J, Soerjomataram I, Dikshit R, Eser S, Mathers C, Rebelo, M, Parkin DM, Forman D, Bray F. Cancer incidence and mortality worldwide: sources, methods and major patterns in Globacan 2012. Int J Cancer 2015; 136: 359-386.

3. Vakaramoko Diaby, Rima Tawk, Vassiki Sanogo, Hong Xiao, Alberto J. Montero. A review of systematic reviews of the cost-effectiveness of hormone therapy, chemotherapy, and targeted therapy for breast cancer. Breast Cancer Res Treat 2015; 151 (1): 27-40.

4. Longley DB, Harkin DP, Johnston PG. 5-fluorouracil: mechanisms of action and clinical strategies. Nat Rev Cancer 2003; 3: 330-338.

5. Nishida M, Kuwahara K, Kozai D, Sakaguchi R, Mori Y. TRP Channels: Their Function and Potentiality as Drug Targets. Innovative Medicine 2015.

6. Clapham DE. TRP channels as cellular sensors. Nature 2003; 426 (6966): 517-524.

7. Patapoutian A, Peier AM, Story GM, Viswanath V. ThermoTRP channels and beyond mechanisms of temperature sensation. Nat Rev Neurosci 2003; 4 (7): 529-539.

8. Clapham DE, Julius D, Montell C, Schultz G. Nomenclature and structure-function relationships of transient receptor potential channels. Pharmacol Rev 2005; 57 (4): 427-450.

9. Voets T, Talavera K, Owsianik G, Nilius B. Sensing with TRP channels. Nat Chem Biol 2005; 1 (2): 85-92.

10. Christensen AP, Corey DP. TRP channels in mechanosensation: direct or indirect activation? Nat Rev Neurosci 2007; 8 (7): 510-521.

11. Bessac BF, Jordt SE. Breathtaking TRP channels: TRPA1 and TRPV1 in airway chemosensation and reflex control. Physiology 2008; 23: 360370.

12. Miller BA, Zhang W. TRP channels as mediators of oxidative stress. Adv Exp Med Biol 2011; 704: 531-544.

13. Kozai D, Ogawa N, Mori Y. Redox regulation of transient receptor potential channels. Antioxid Redox Signal 2014; 21 (6): 971-986.

14. Simon F, Varela D, Cabello-Verrugio C. Oxidative stress-modulated TRPM ion channelsin cell dysfunction and pathological conditions in humans. Cell Signal 2013; 25 (7): 1614-1624.

15. Toledoa AS, Espinoza-Gabriela MI, Condadoc DM. Evaluation of the TRPM2 channel as a biomarker inbreast cancer using public databases analysis. Bol Med Hosp Infant Mex 2016; 73 (6): 397-404.
16. Sumoza-Toledo A, Penner R. TRPM2. A multifunctional ionchannel for calcium signalling. J Physiol 2011; 589 (7): 1515-1525.

17. Park YR, Chun JN, So I, Kim HJ, Baek S, Jeon JH et al. Data-driven analysis of TRP channels in cancer: linking variation ingene expression to clinical significance. Cancer Genomics Pro-teomics 2016; 13: 83-90.

18. Doerner JF, Gisselmann G, Hatt H, Wetzel CH. Transient receptor potential channel A1 is directly gated by calcium ions. J Biol Chem 2007; 282 (18): 13180-13189.

19. Gou H, Gu L, Shang B et al. Protective effect of Bu-Zhong-Yi-Qi decoction, the water extract of Chinese traditional herbal medicine, on 5 -fluorouracil-induced intestinal mucositis in mice. Hum Exp Toxicol 2016; 35 (12): 1243-1251.

20. Kart A, Cigremis Y, Karaman M et al. Caffeic acid phenethyl ester (CAPE) ameliorates cisplatin-induced hepatotoxicity in rabbit. Exp Toxicol Pathol 2010; 62 (1): 45-52.

21. Han Q, Chen R, Wang F, Chen S, Sun X, Guan X et al. Pre-exposure to $50 \mathrm{~Hz}$-electromagnetic fields enhanced the antiproliferative efficacy of 5-fluorouracil in breast cancer MCF-7 cells. PLoS One 2018; 13 (4): $\mathrm{e} 0192888$.

22. Tedeschi PM, Kathari YK, Farooqi IN, Bertino JR. Leucovorin rescue allows effective high-dose pralatrexate treatment and an increase in therapeutic index in mesothelioma xenografts. Cancer Chemother Pharmacol 2014; 74 (5): 1029-1032.

23. Uğuz AC, Naziroğlu M, Espino J, Bejarano I, González D, Rodríguez AB, Pariente JA. Selenium modulates oxidative stress-induced cell apoptosis in human myeloid HL-60 cells through regulation of calcium release and caspase-3 and -9 activities. J Membr Biol 2009; 232 (1-3): 15-23.

24. Martinez NA, Ayala AM, Martinez M, Martinez-Rivera FJ, Miranda JD, Silva WI. Caveolin-1 Regulates the P2Y2 Receptor Signaling in Human 1321N1 Astrocytoma Cells. J Biol Chem 2016; 291 (23): 12208-12222.

25. Espino J, Pariente JA, Rodríguez AB. Role of melatonin on diabetesrelated metabolic disorders. World J Diabetes 2011; 2 (6): 82-91.

26. Özdemir ÜS, Nazıroğlu M, Şenol N, Ghazizadeh V. Hypericum perforatum attenuates spinal cord injury-induced oxidative stress and apoptosis in the dorsal root ganglion of rats:involvement of TRPM2 and TRPV1 channels. Mol Neurobiol 2016; 23: 1-12.

27. Espino J, Bejarano I, Redondo PC, Rosado JA, Barriga C, Reiter RJ et al. Melatonin reduces apoptosis induced by calcium signaling in human leukocytes: Evidence for the involvement of mitochondria and Bax activation. J Membr Biol 2010; 233 (1-3): 105-118.

28. Bejarano I, Redondo PC, Espino J, Rosado JA, Paredes SD, Barriga C, Reiter RJ, Pariente JA, Rodríguez AB. Melatonin induces mitochondrial-mediated apoptosis in human myeloid HL-60 cells. J Pineal Res 2009; 46 (4): 392-400.

29. Öz A, Çelik Ö. Curcumin inhibits oxidative stress-induced TRPM2 channel activation, calcium ion entry and apoptosis values in SH-SY5Y neuroblastoma cells: Involvement of transfection procedure. Mol Membr Biol 2016; 33 (3-5): 76-88.

30. Uguz AC, Cig B, Espino J, Bejarano I, Naziroglu M, Rodríguez AB, Pariente JA. Melatonin potentiates chemotherapy-induced cytotoxicity and apoptosis in rat pancreatic tumor cells. J Pineal Res 2012; 53 (1): 91-98.

31. Övey IS, Naziroğlu M. Homocysteine and cytosolic GSH depletion induce apoptosis and oxidative toxicity through cytosolic calcium overload 


\section{$692-700$}

in the hippocampus of aged mice: involvement of TRPM2 and TRPV1 channels. Neuroscience 2015; 284: 225-233.

32. Khalil M, Alliger K, Weidinger C, Yerinde C, Wirtz S, Becker C et al. Functional Role of Transient Receptor Potential Channels in Immune Cells and Epithelia. Front. Immunol 2018: 9: 174.

33. Van Goor MKC, Hoenderop JGJ, van der Wijst J. TRP channels in calcium homeostasis: From hormonal control to structure-function relationship of TRPV5 and TRPV6. Biochim. Biophys. Acta 2017; 1864: 883-893.

34. Najder K, Musset B, Lindemann O, Bulk E, Schwab A, Fels B. The function of TRP channels in neutrophil granulocytes. Pflüg. Arch. Eur J Physiol 2018; 470 (7): 1017-1033.

35. Fels B, Bulk E, Petho Z, Schwab A. The Role of TRP Channels in the Metastatic Cascade. Pharmaceuticals 2018; 11 (2): 48-73.

36. Wang T, Chen, Zhu Y, Pan O, Liu Y, Qi X et al. Inhibition of Transient Receptor Potential Channel 5 Reverses 5-Fluorouracil Resistance in Human Colorectal Cancer Cells The Journal of Biological Chemistry 2015; 290 (1): 448-456.

37. Ouadid-Ahidouch H, Dhennin-Duthille I, Gautier M, Sevestre H, Ahidouch A. TRP channels: diagnostic markers and therapeutic targets for breast cancer? Trends Mol Med 2013; 19 (2): 117-124.
38. Sergeev IN. Calcium signaling in cancer and vitamin D. J Steroid Biochem Mol Biol 2005; 97 (1-2): 145-151.

39. Sun Y, Huang L, Mackenzie GG, Rigas B. Oxidative stress mediates through apoptosis the anticancer effect of phosphononsteroidal antiinflammatory drugs: implications for the role of oxidative stress in the action of anticancer agents. J Pharmacol Exp Ther 2011; 338: 775-783.

40. Nazıroglu M. New molecular mechanisms on the activation of TRPM2 channels by oxidative stress and ADP-ribose. Neurochem Res 2007; 32: 1990-2001.

41. Espino J, Bejarano I, Paredes SD, Gonzalez D, Barriga C, Reiter RJ et al. Melatonin counteracts alterations in oxidative metabolism and cell viability induced by intracellular calcium overload in human leucocytes changes with age. Basic Clin Pharmacol Toxicol 2010; 107: 590-597.

42. Deveci HA, Nazıroglu M, Nur G. 5-Fluorouracil-induced mitochondrial oxidative cytotoxicity and apoptosis are increased in MCF-7 human breast cancer cells by TRPV1 channel activation but not Hypericum perforatum treatment Mol Cell Biochem 2018; 439 (1-2): 189-198.

43. Chen Z, Zhu Y, Dong Y, Zhang P, Han X, Jin J, Ma X. Overexpression of TrpC5 promotes tumor metastasis via theHIF-1_-Twist signaling pathway in colon cancer. Clin. Sci. Lond. Engl 1979 2017; 131: 2439-2450.

Received July 7, 2018. Accepted August 16, 2018. 